\title{
Curriculum in the Post Truth Era: Is Truth Dead?
}

\author{
James Colin Field \\ Werklund School of Education \\ University of Calgary \\ jfield@ucalgary.ca
}

"Trump has discovered something about epistemology in the $21^{\text {st }}$ Century. The truth may be real, but falsehood often works better" (Scherer, M., Time, April 3, 2017).

Ironically perhaps, I took what the Donald has discovered about Western epistemology in our age to be true, so my first cautious answer to the question posed in the title is a qualified yes: Truth might indeed be dead, or at least dying, in the same way that Nietzsche proclaimed, more than 100 years ago, that God is dead. I think it's important to note that Nietzsche wasn't proclaiming that God did not exist, rather, he was stating that his existence has ceased to matter in the sense of bringing order, commitment, and a sense of purpose to a secular society.

So, the question for me is not does truth exist? That is, can we sort truth from lies, or the "fake news" from the factual reporting of important events, and from the false histories constructed through colonial, imperial, racist, or homophobic discourses? I do think that is a very important task, and a very real threat to living together in truth. Hanna Arendt (1948/1976) has provocatively asserted that the inability of the masses to sort the truth from lies is the primary condition for the rise of totalitarianism and the rule of strong men, and we might add, the election and possible re-election of Donald Trump. But that is another conversation that takes me away from my primary concern.

Here then is the question restated simply: Does the truth matter? It doesn't to the $28 \%$ of the people who, finding Donald Trump neither truthful nor reliable, voted for him anyways (Scherer, 2017). Does the truth that emerged from the Truth and Reconciliation Commission matter? Does it matter that over 15,000 people were killed with guns in 2017 in the US, almost 4,000 of those children, that mass school shootings, 500 since Sandi Hook Elementary in 2013, occupy monthly new cycles (Gun Violence Archive, 2018)? Does it matter that we continue to destroy the earth in our relentless, capitalist and imperialist pursuit of what Jason Moore (2016) calls "the four cheaps: food, energy, raw material, and human life" (p. 11)?

To expand on the question a little, does the truth move us sufficiently, first, to pay attention, amid all the noise and the avalanche of mundane information, to see, to listen, to feel, to be addressed such that we cannot turn away? Can the truth orient $u \mathrm{~s}$, that is, have sufficient force to turn us to face our problems squarely? Does it have enough of a hold on our lives to bring us together collectively, to act, and to persevere in those actions through what will surely be tremendous suffering and difficulty?

I think the lack of significant and sustained action in the face of these life and planetthreatening problems confirms what Nietzsche claimed over 100 years ago: a deep-seated logic has worked its way out inside the Western tradition: that of nihilism. What this means can be summarized, perhaps too briefly, with a statement from Nietzsche himself: "What does nihilism mean? That the uppermost values de-valuate themselves. The aim is lacking; the 'why' receives 
no answer" (as cited in Heidegger, 1961/1987, p. 203). God, truth and nature are but three examples of this devaluation; one that results in what Nietzsche called its "completed form" in meaninglessness. By meaninglessness, I am not asserting that things don't make sense, quite the opposite in fact, everything makes sense, and we are overwhelmed by a flood of mundane and superficial meaning. This then is Nietzsche's "life without why," in the face of what Martin Heidegger (1928/1999) called the "facticity of our lives": the violence, suffering, and destruction that comes from the treatment of the earth and all its occupants, as if they were simply standing reserve for our projects (p. 3).

Technology has not helped us solve this problem. Perhaps it is naive of us to think that it could; it has after all done much to cause the very conditions of nihilism itself: the devaluation of knowledge into highly mobilized, placeless, and consumable information. An unrelenting data storm is upon us, it seems. What arises under such conditions, according to Arthur Kroker (2004), is the complete unleashing of the will to power, a technological will, that results in what he calls cynical truth, which

...knows only media effects. It migrates across different media. It changes state as it seeks points of maximum intensity for communication with a humiliated public. It is without history because it leaves no fixed electronic trail. Its truth value depends precisely on its articulation of perspectives that strengthen movements towards fear, panic, insecurity, and redemptive violence...it ruptures that deep connection between truth-saying and the responsibilities of democratic citizenship. (p. 168)

It is this rupture between truth seeking, truth-saying, and responsibility that I am most concerned with, because the rupture contributes to a fading ethical sensibility. The call to do something, to pay attention sufficiently to consider the depth, complexity and urgency of things is swept away in the data storm of incessantly streaming capitalism, served up for hyper-perception by the digital eye/I. The effect is both mundane and frightening, what Arendt thought was the most terrifying evil of all, common thoughtlessness, that has the effect of what Kroker (2014) calls "the moral equivalent of nothingness" (p. 170). With a loss in the import of truth comes a fading of ethical sensibility, and with that, a disappearing sense of responsibility-for each other and for the-more-than-human-world. To return, this is how Nietzsche's life without why, cashes out and is linked to a life without what, or at least a lethally reduced what: simply for profit.

So, if this is the fix we are in, then what is the way out? I feel compelled to make an attempt here at an answer, if only to heed my father's advice: criticism son, is a job half done. But I realize that this is also a dangerous question to answer because another troubling question arises: Who am I to say? Who am I to tell the world it needs to pay attention? And so a confession is in order before I begin. I acknowledge that any attempt at providing an answer, or $a$ way out of the mess will be partial at best, that it might get a hold of something that is true, but it is also likely to misunderstand the truth at the same time, that it might reveal something that we need to pay attention to, but likely conceal a whole lot more. I ask for your forgiveness for the latter, long enough at least to consider my plea.

$* * *$

At this point in the paper I have those three little dots, stuck there because I cannot find a suitable segue between horror and hope - and so I ask you to leap with me over the abyss to what I think is the way forward. 
I'll begin in my own tradition, to see if it will do, as a start, with the words (yet again) of Hanna Arendt (1954/1968). These have been often quoted, but I like to repeat them here, to help them become sedimented, in my being, at the level of the molecule. Perhaps it is there, like a kind of bone marrow transplant, they will help me do some good in a good way. She says:

Education is the point at which we decide whether we love the world enough to assume responsibility for it, and by the same token save it from the ruin, which, except for renewal, except for the coming of the new and the young, would be inevitable. (Arendt, 1954/1968, p. 193)

In speaking of love in education, indeed, in calling for it, I feel the need to say what love is not, because some of the vilest things in education have been committed in the name of love. I do not mean foolish love, often characterized as brute and blind, which would put us at unnecessary risk in a dangerous relationship. I do not mean social contract love, the kind that would require something in return or in advance from the other. I do not mean narcissistic self-love, in the service of self-aggrandizement and self-promotion, so prevalent in the world today. I do not mean love as a Trojan horse, where harm is smuggled into the relationship and destroys it from within. I do not mean love as salvation, something that would save us from suffering, or deliver us from evil. I mean love that is conditioned by wisdom, love that is girded by vigilance, a discerning kind of love that arms us, lovingly, for action.

Where does love like this begin? Below the level of consciousness, I think, in what Andreas Weber (2017) calls love as

... the principle of a fulfilling equilibrium between the individual and the whole. The erotic manifests as that force that causes beings to in-exhaustively seek this equilibrium... The power of the erotic suffuses the biosphere with life and imbues its members with the stamina to look-with new verve every day-for fruition, fulfillment and joy. (p. 7)

According to Weber (2017), this erotic connection occurs at the level of metabolism, it has nothing to do with our wanting and doing, nothing to do with our willful construction of reality. Love begins before knowledge, in a fundamental relationship with the surround:

The functioning of the circle of life on earth depends solely on the fact that we all share in the great body of matter and pass through one another reciprocally. Life is touch in a much deeper sense than just touching skin to skin, in colliding with masses foreign to us. It is touch as penetration of one another by another. The existence of each one of us, plants, animal cells, I as a human being, depends solely on the mutual relatedness, manifested in the exchange. (p. 57)

This kind of inevitable, mutual relatedness requires that I respond to a much deeper call, the call of love for serving the unfolding of life and death itself, in servitude to the sacred relationships that make our lives possible, with all the courage and veracity I can muster.

$* * *$

What I have only hinted at here is not for our own utopian salvation, and certainly not the kind of love that would seek life at any cost, but rather the call of an ethical relation to the other: 
cell, animal, plant, planet, and perhaps most of all, what is most distant to our knowing, willing selves, unfathomable mystery. Paul Ricoeur helps me with his declaration that the call between humans, is the call issued to us as a love command, issued from what is other to us, that addressees us in the second person: you, and you, and you, and me. For Ricoeur (1992), it is the first command made upon us: "To live well with and for others in just institutions" (p. 251). Yes, even in Eurocentric institutions, steeped in hierarchical power structures, in systemic racism and sexism, in lateral violence and ever more, in bureaucratic proceduralism. After Ricoeur, David Hall (2007), in laying out what the love command is, expands on the notion of responsibility:

My holding myself responsible for my actions only becomes meaningful in a moral sense within the realm of my responsibility to another, and their moral claim on me, a claim to which I am receptive in moral concern... promising is not merely a matter of remaining constant in the future to the word I live in the present, it is also a matter of being open to the other's expectation that I will keep the promise I have given. (p. 155)

The work required, to determine together what it means to live well with and for others, and to live in just institutions, and not to foreclose too early on that difficult, power-laden conversation, not to marinate it in Eurocentrism, will not be easy, nor will it come quickly. Nor do I think this is a conversation about knowledge or truth per se, but rather: Does truth matterenough so that we will be able to endure the long arduous, painful struggle that is required?

Back to schools and curriculum, for a moment, if you will allow me, in closing, to restate that Arendt's insight — that we begin in love and not in knowledge, as we so often do in schools - is fundamental to finding a way forward. If I may be as bold as to suggest, the place to begin in curriculum and in classrooms, is not with Herbert Spencer's age-old question, one that has dominated curriculum since the beginning of school, that is, Which knowledge is of most worth? A pedagogy of love in a Social Studies classroom, cannot begin with adult expectations, predetermined outcomes, assignment specifications, the rules of order, or with the securing of epistemological security through building a rubric. Let us cross that Rubric-con, please (forgive me, I couldn't resist). Rather, and I thank Dwayne Huebner (1999) for this, the place to begin is with Nietzsche's question: What (in the world) have you loved until now? There it is, it might be that simple: write it, lovingly, on the white board, in red. Ask for silent contemplation, and just as the quiet spell begins to break, for a few scribbled thoughts on what, in the world, is worth loving. Push the ensuing discussion critically, that is arm the love, so that it isn't seen as softheaded and naïve, and something that can be easily dismissed: What kinds of love threaten or diminish life (and self)? What kinds masquerade as love? What kinds, in Bob Dylan's words, give us shelter from the storm that would otherwise destroy us?

I do not think we cultivate love for the world, and reverence for the life it gives, the gift of love from the world, in schools. I cannot find the term in any program of study, or any list of outcomes. I have yet to encounter it in a standardized test of achievement. And yet, what is the point of learning anything if it isn't about cultivating love: tying oneself to the world, caring enough about it, being enraptured by it, to the point of developing permanent, responsible relations with it? Without loving attachment, it is unclear to me what would ever motivate us to take the risks required, and to persevere through the suffering and difficulty, for the sake of justice. How else could we pierce the fog of fear, anger, cynicism, the inertia of apathy, or the consumptive power of greed, if it isn't with love, and its allies among the emotions: reverence, 
grief, compassion, and forgiveness? Can we be bold enough to say that our curriculums need to deliberately cultivate these emotions in order to fulfill what is needed in today's world to be a good citizen, to live together well in good citizenship? Is this not work that is central to Social Studies?

Is love alive in the world? I think this is the real question, because if it is, surely, we can bring truth back to life, and have it be an animating force in the world, have it be truth fed and armed with love, a weapon of mass compassion.

\section{References}

Arendt, H. (1954/1968). Between past and future. New York, NY: Penguin Books.

Arendt, H. (1948/1976). Totalitarianism, part three of the origins of totalitarianism. New York, NY: Harcourt.

Gun Violence Archive. (November, 2018). Retrieved from https://www.gunviolencearchive.org/past-tolls

Hall, D. (2007). Paul Ricoeur and the poetic imperative: The creative tension between love and justice. New York, NY: SUNY.

Heidegger, M. (1928/1999). Ontology: The hermeneutics of facticity. Bloomington, IA: Indiana University Press.

Heidegger, M. (1961/1987). Nietzsche: The will to power as knowledge and as metaphysics (Vol. 3). New York, NY: Harper and Row.

Huebner, D. (1999). The lure of the transcendent. Mehwah, NJ: Lawrence Erlbaum Publishers.

Kroker, A. (2004). The will to technology and the culture of nihilism. Toronto, ON: University of Toronto Press.

Kroker, A. (2014). Exits to the posthuman future. Cambridge, MA: Polity.

Moore, J. (2016). (Ed.). Anthropocene or capitalocene? Nature, history, and the crisis of capitalism. Oakland, CA: PM.

Ricoeur, P. (1992). Oneself as another. Chicago, IL: University of Chicago Press.

Scherer, M. (2017, April). Can President Trump Handle the Truth? Time, 18(12). Retrieved from http://time.com/magazine/us/4710599/april-3rd-2017-vol-189-no-12-u-s/

Weber, A. (2017). Matter and desire: An erotic ecology. White River Junction, VT: Chelsea Green. 